\title{
歩行器の転倒防止装置の開発の為の転倒判断指標の検討
}

\section{Examination of Turnover Judgment Indicators for Turnover Prevention Device of Walker}

上福元 裕一 ${ }^{* 1}$ (学生員), 和多田 雅哉 ${ }^{* 1}$ (正員), 山田 睦雄 ${ }^{* 2}$ 渡辺 一郎 ${ }^{* 1}$, 椿原 徹也 ${ }^{* 1}$, 佐藤 広隆 ${ }^{*{ }^{*} 3}$

Yuichi KAMIFUKUMOTO(Stu. Mem.), Masaya WATADA, Mutuo YAMADA Ichirou WATANABE, Tetsuya TSUBAKIHARA, Hirotaka SATO

\begin{abstract}
Elderly and physically handicapped persons are increasing in japan. They decreased physical ability, it is difficult to ADL. Support of their ADL is an important issue. Independent walking is important in ADL. The walker is support equipment to independent walking. But turnover is problem in walk with the walker. In this study, to develop of turnover prevention device of the walker. Definition of turnover judgment is not established at this stage. First, establish turnover judgment indicators. In this paper, we measure action and force and speed, were investigated turnover judgment indicators. And, focusing on force acting on the walker, examined the indicators by time variation of force.
\end{abstract}

Keywords: assistive products, walker, turnover prevention device.

\section{1 緒言}

現在，日本は高齢化が進んでいる。高齢者はW.H.O により 65 歳以上と定義する。2015 年での日本の総人 口の約 $25 \%$ は高齢者と予測されており, 2060 年には約 40\%に増加すると言われている。Fig. 1 に, 日本の総人 口と高齢者数の年次推移を示す $[1]$ 。また，身体障害者 の数も年々増加している[2]。高齢者や身体障害者は老 化・障害により, 日常生活を営む上で必要不可欠な A.D.L.( Activities of Daily Living : 日常生活動作)が困難 となる。今後, 高齢者や身体障害者はさらに増加する 事から, 彼らのA.D.L.の改善・支援は大きな課題であ る。A.D.L を評価する指標の一つとして「独力で歩行 し外出する事が可能か」が判断基準とされ, 高龃者ら の独力での歩行はA.D.L.の中でも重要な要素であると 考える[3]。

高齢者らの独力での歩行を支援する移動支援機器 として, 歩行器が用いられる。歩行器は独力での歩行 が比較的困難な者が使用する場合が多く, 外出を想定 し籠や座面の付いたタイプも普及している。しかし歩 行器の使用における課題の 1 つとして, 転倒による事 故が挙げられる。先行研究によると歩行器を使用する

連絡先：上福元 裕一, $\bar{\top} 158-8557$ 世田谷区区玉堤 1-281, 東京都市大学大学院工学研究科生体医工学専攻, e-mail: g1481405@tcu.ac.jp

${ }^{* 1}$ 東京都市大学 ${ }^{* 2}$ 流通経済大学 ${ }^{* 3}$ 東大和病院 臨床 工学科
高齢者の多くが転倒経験や，転倒しそうになった経験 を有していた[4]。そこで本研究では，高齢者らの自立 した生活の支援を目的に，高齢者らの生活範囲の拡大 に対応した移動全体を包括する転倒防止装置を開発す る。本稿では，転倒防止装置に必要な転倒判断指標を 確立する為, 歩行器から計測可能な要素として力と速 度，転倒を確認する為の要素として身体の軌跡の計測 を行い, 転倒判断に有用な指標ついて検討し述べる。

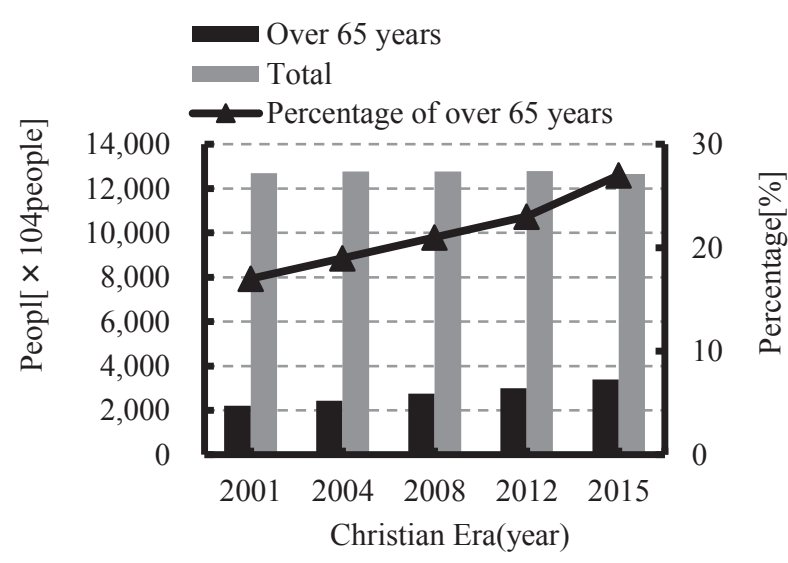

Fig. 1 Population changes in over 65 years. 


\section{2 転倒防止装置と転倒判断指標}

\section{1 転倒防止装置の概要}

本装置では，歩行器の速度や使用者の動作，路面の 状況から車体を制御し歩行を補助する。また, 上り坂 では少ない力で移動出来る様に，下り坂ではブレーキ を掛け加速を防ぐ事で安定性を高め転倒を防止する。

Fig. 2 に転倒防止装置のシステム概要を示す。

歩行全体を包括した転倒防止装置を開発する上で, どの指標を用いて転倒を予測するかが重要である。し かし現段階において，転倒判断指標が明確に定義され ていない。そこで本研究では，まず転倒を判断する為 の指標を確立する。先行研究より身体の軌跡において, 転倒特有の傾向が報告された[5]。しかし使用者の身体 の軌跡を測定には，使用者に測定点を示寸為のマーカ を装着する必要がある。その為, 身体の軌跡を判断指 標にしまうと, 高齢者らは歩行器を使用する度にマー カを装着しなければならず，使用者に負担を与えてし まう。そこで歩行器にセンサを取り付け速度や歩行器 に作用する力を計測する。速度や歩行器に作用する力 と，使用者の身体の軌跡の相関性を検討寸る事で，使 用者の姿勢を速度や力から間接的に検知する。

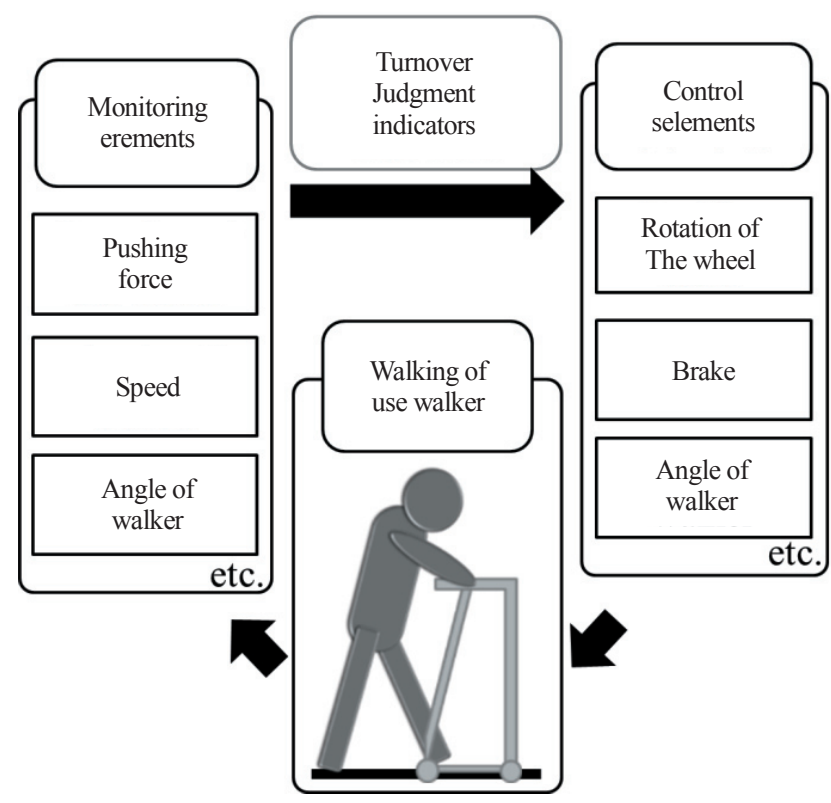

Fig. 2 System of turnover prevention device.

\section{3 転倒判断要素の選定}

使用者や歩行器の速度 - 加速度を動画解析から, 歩 行器に作用寸る力を荷重計測から求める[6]。Fig. 3 に 計測を行う歩行器に作用する力を示す。

転倒時，使用者及び歩行器の速度・加速度が瞬間的 に増加すると考えられる。同様に，転倒時は歩行器に 作用寸る力が増加寸ると考えられる。

歩行器に作用する力は, 使用者が歩行器を操作する 力 $F$ が掛かると考える。これは，歩行器を前に押し出 寸力 $F_{\mathrm{x}}\left(F\right.$ の $x$ 方向成分) と歩行器に体重を掛ける力 $F_{\mathrm{z}}$ $\left(F\right.$ の $z$ 方向成分) 合力である。よって本研究では $F_{\mathrm{x}}$ と $F_{\mathrm{z}}$ を計測し, 以下の式から $F$ と $F$ の成方角度 $\theta_{\mathrm{F}}$ を 求める。

$$
\begin{gathered}
|\vec{F}|=\sqrt{\left|\overrightarrow{F_{\mathrm{X}}}\right|^{2}+\left|\overrightarrow{F_{\mathrm{Z}}}\right|^{2}} \\
\theta_{\mathrm{F}}=\tan ^{-1} \frac{\left|\overrightarrow{F_{\mathrm{Z}}}\right|}{\left|\overrightarrow{F_{\mathrm{X}}}\right|}
\end{gathered}
$$

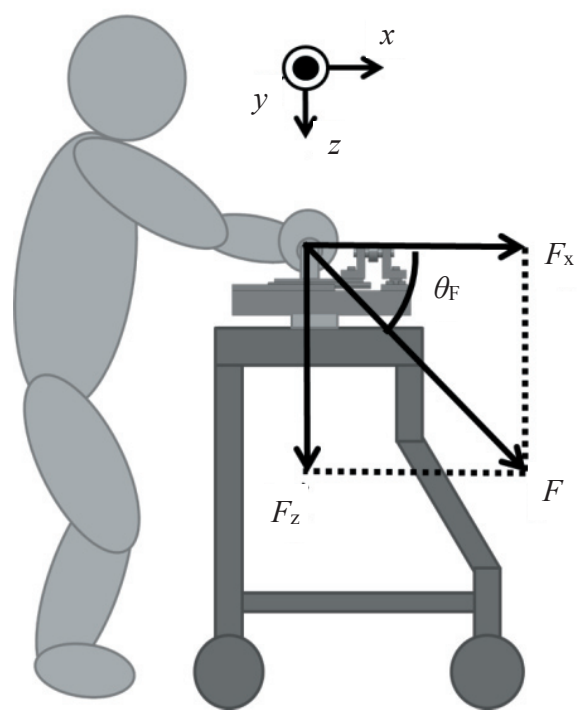

Fig. $3 X$-direction component and $Z$-direction component to the force of walker.

\section{3 歩行器を用いた模擬転倒実験}

歩行器の速度と作用する力から転倒を判断する為 に，速度と力と身体の軌跡の計測を行った。 


\section{1 実験方法}

歩行器の速度, 身体の軌跡はビデオカメラ(SONY 社 製)で撮影し，撮影した動画を $30 \mathrm{~Hz}$ の連続静止画に変 換する。連続静止画から移動距離を MOA-2B を, 関節 角度を Image-J を用いてマーカ座標をプロットし算出 した。算出した移動距離, 関節角度を MATLAB/Simulink を用いて 1 回微分して速度を, 2 回 微分して加速度を算出した。また, 微分に加速度を求 める際，マーカの座標をプロットする際に発生した離 散化誤差の影響を除く為に遮断周波数 $0.4 \mathrm{~Hz}$ のローパ スフィルタに通してから算出した。

歩行器に作用する力は荷重計測の測定用ハンドル を用いて計測する。歩行器(カワムラサイクル社製 KW15N-L)に，製作した荷重計測用ハンドルを装着す る。被験者が歩行器を押し引きする力 $F_{\mathrm{x}}$ はハンドル中 央に取り付けた引張圧縮両用ロードセル LUR-A$1 \mathrm{KNSA} 1$ (共和電業社製)を用いて, 被験者が歩行器に 身体を押し付ける力 $F_{\mathrm{z}}$ は測定用ハンドルの台座に取 り付けた圧縮用ロードセル LMA-A-1KN (共和電業社 製)を取り付け計測する。ロードセルの測定值を PCD$300 \mathrm{~A}$ (共和電業社製)を用いて PC に取り込む。歩行器 に作用する力は歩行器を押し引きする力 $F_{\mathrm{x}}$, グリップ 右下部に身体を押し付ける力 $F_{\mathrm{z} 1}$, グリップ左下部に身 体を押し付ける力 $F_{\mathrm{z} 2}$ の計 3 チャンネルを計測する。

$F_{\mathrm{z} 1}, F_{\mathrm{z} 2}$ から歩行器に身体を押し付ける力 $F_{\mathrm{z}}$ を算出す る。Fig. 4 に模擬転倒実験の計測システムを示す。

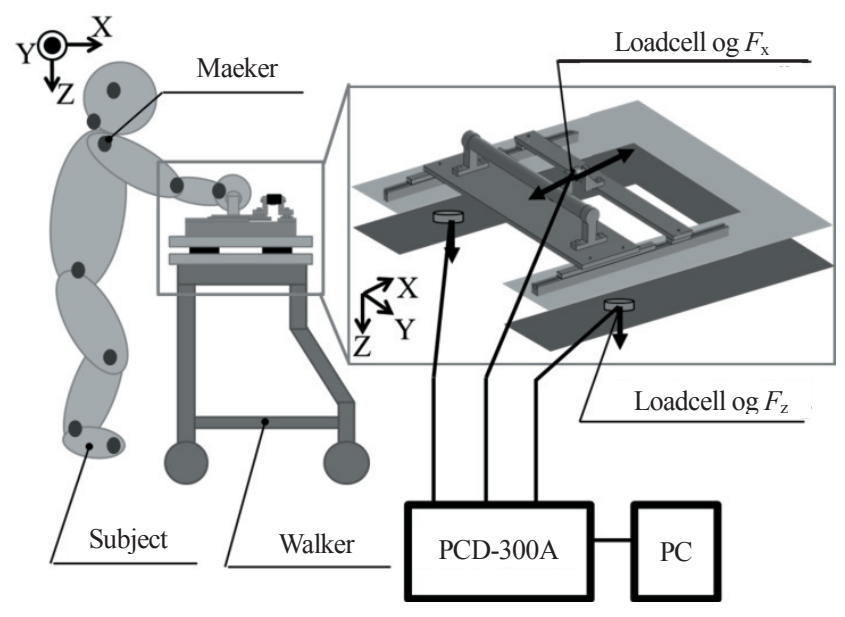

Fig. 4 Overview of the measurement system of force.
被験者には $3 \mathrm{~m}$ の直進路を歩行器を押して 5 歩歩い てもらった。被験者は健常な男性成人(22 歳, 身長 165 $\mathrm{cm}$, 体重 $58 \mathrm{~kg}$ ) とした。また高齢者の歩行を再現する 為に，高齢者体験キットまなび体を同被験者に装着し た。腰が曲がる事による前傾姿勢の再現には, 前面に 重りを入れたジャケットを着用した。老化による肘と 膝の可動範囲の減少の再現には, 肘当て膝当てを装着 し可動範囲を制限した。

マーカの取付位置は被験者の体幹や関節の動きを 観察寸る為頭, 首, 肩, 肘, 手首, 腰, 膝, 踝, つま 先の 9 箇所とした。被験者の身体の軌跡では, 歩行周 期を検出する為の膝の関節角度 $\theta_{\mathrm{k}}$, 歩行器の操作に影 響を及ぼすと考えられる肘の関節角度 $\theta_{\mathrm{e}}$, 先行研究で 転倒時の特徵が見られた大転子と足首からなる角度 $\theta_{0}$, を選定した。Fig. 5 に選定した関節角度を示寸。

\section{2 実験結果}

Fig. 6 に健常者の $F_{\mathrm{x}}$ と $F_{\mathrm{z}}$ と速度と各関節角度の転倒 実験の結果を, Fig. 7 に模擬高齢者の $F_{\mathrm{x}}$ と $F_{\mathrm{z}}$ と速度と 各関節角度の転倒実験の結果を示す。図上部の写真は それぞれ動作の経時変化を表している。時間軸上の 2 本の黒い実線は，それぞれ歩行から転倒への移行開始 を示す転倒開始線と, 転倒による立ち直り反射(保護進 展反応)を示寸立ち直り反射線とする。

Fig. 6 及び Fig. 7 より, 速度 $v$ と加速度 $a$ では転倒時の 変化が立ち直り反射，即ち被験者が静止立位を保てな くなった後に起きている。転倒を防止する為には歩行 から転倒への移行開始(さらに移行寸る前)での転倒判 断が必要である。よって転倒後に変化する $v$ と $a$ は, 転倒判断指標には適していない。

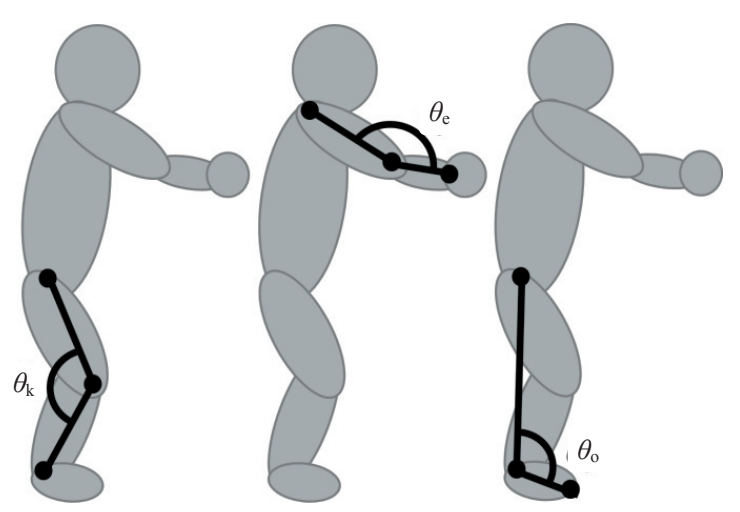

Fig. 5 Setting the angle of elbow and knee, ankle. 

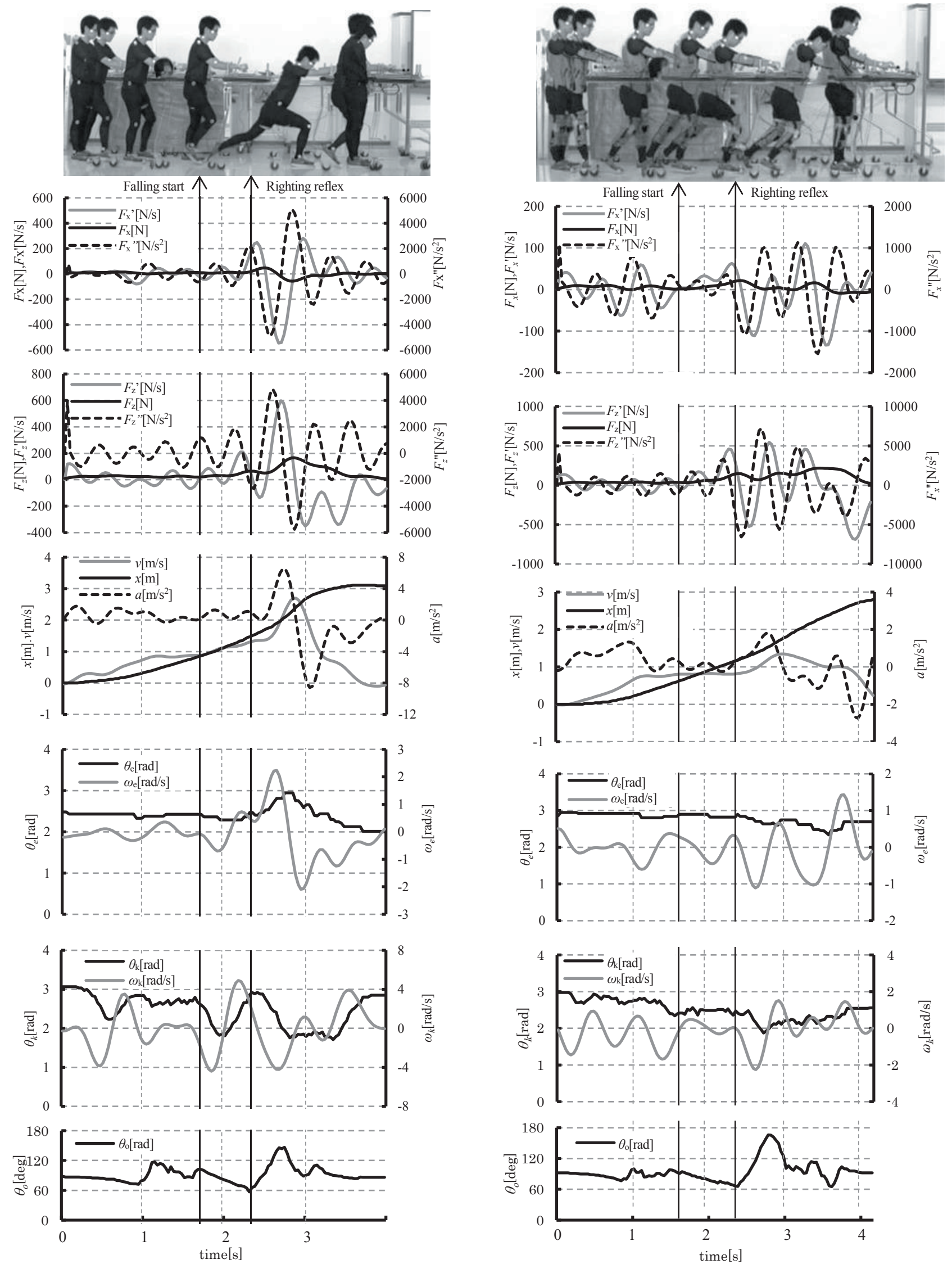

Fig. 6 Change of $F_{x}$ and $F_{z}$, Speed, Joint angle in overturn (Able-bodied person).

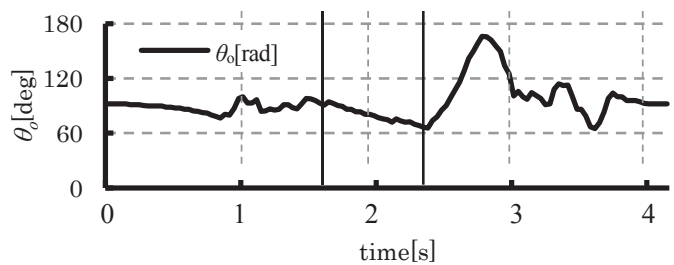

Fig. 7 Change of $F_{x}$ and $F_{z}$, Speed, Joint angle in overturn (Simulated elderly people). 
Fig. 6 及び Fig. 7 より, 歩行器を押し引きする力 $F_{\mathrm{x}}$ と歩行器に身体を押し付ける力 $F_{\mathrm{z}}$ も, 転倒時の変化が 見られた。さらに時間変化である $F_{\mathrm{x}}{ }^{2}$ と $F_{\mathrm{z}}{ }^{\prime}, F_{\mathrm{x}}{ }^{\prime}$ と $F_{\mathrm{z}}{ }^{\prime}$ では転倒開始直後から力の変化を測定する事が出来た。 よって歩行器へ作用する力が転倒判断指標として有効 であると言える。そこで $F$ の $x$ 方向成分である $F_{\mathrm{x}}$ と $z$ 方向成分である $F_{\mathrm{z}}$ から, 使用者が歩行器を操作する力 $F$ と $F$ の成市角度 $\theta_{\mathrm{F}}$ を求めた。

Fig. 8 に健常者の力の合成の結果を, Fig. 9 に模擬高 齢者の力の合成結果を示す。時間軸上の 2 本の黒い実 線は，Fig. 6 及び 7 と同様に転倒開始と立ち直り反射 である。

Fig. 8 及びFig. 9 より, 健常者, 模擬高龃者共に $\theta_{\mathrm{F}}$ が 70〜90 度となっておいた。この事から F は歩行, 転倒 共に歩行器に対して垂直に掛かっていると言え， $F_{\mathrm{z}}$ が そのまま $F$ となっている事が判明した。そこで時間変 化である $F$ 'と $F_{\mathrm{z}}{ }^{\prime}, F$ ' $F^{\prime} F_{\mathrm{z}}$ ”を算出した。

Fig. 10 に健常者の $F^{\prime}, F_{\mathrm{z}}{ }^{\prime}, F^{\prime}{ }^{\prime}, F_{\mathrm{z}}{ }^{\prime}$ を, Fig. 11 に 模擬高齢者の $F^{\prime}, F_{\mathrm{z}}, F^{\prime}, F_{\mathrm{z}}$ ”を示す。時間軸上の 2 本の黒い実線は，Fig. 6 及び 7 と同様に転倒開始と立 ち直り反射である。横軸に水平な黒い破線は, 歩行時

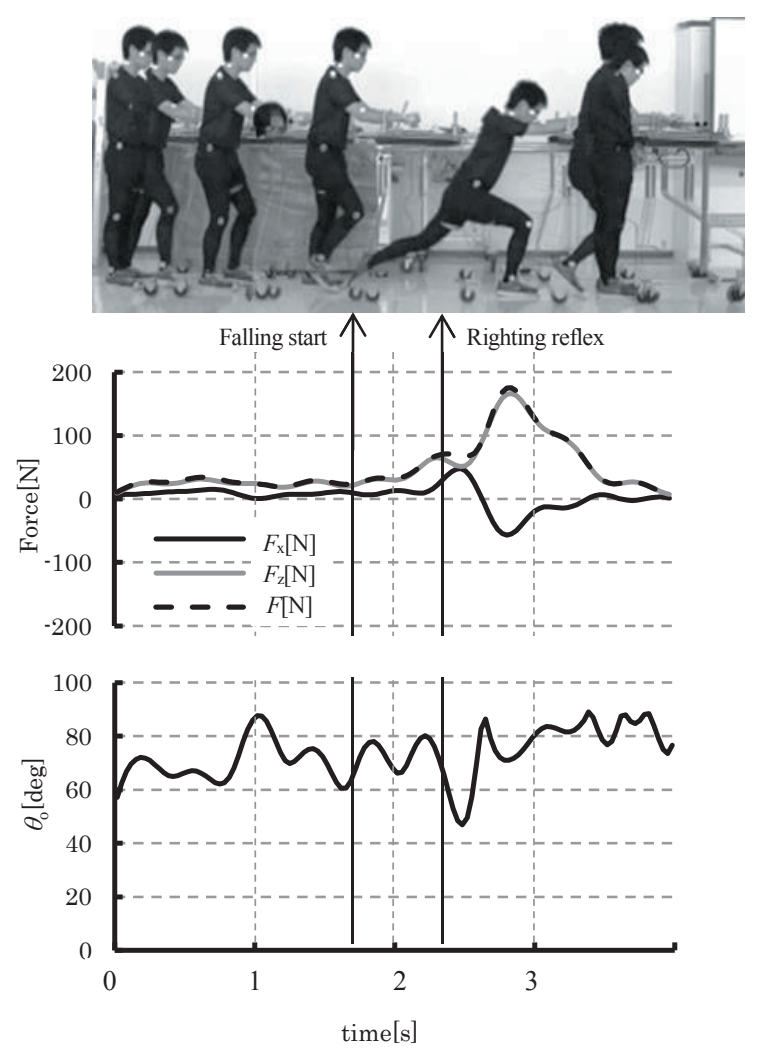

Fig. 8 Calculation of Resultant force $F$ and Direction $\theta$ (Able-bodied person).
の $F_{\mathrm{z}}{ }^{\prime}, F_{\mathrm{z}}$ " $の$ 最大值, 即ち歩行から転倒への閾值を示 している。時間軸上の黒い破線は， $F_{\mathrm{z}}$ ’が閾值を超えた 瞬間を示している。

Fig. 10 より, 健常者の歩行中の $F_{z}$ 'の最大值は 70.5 $\mathrm{N} / \mathrm{s} ， F_{\mathrm{z}}$ ”の最大值は $883.7 \mathrm{~N} / \mathrm{s}^{2}$ であった。Fig. 11 より, 模擬高齢者の歩行中の $F_{\mathrm{z}}$ 'の最大值は $86.8 \mathrm{~N} / \mathrm{s}, F_{\mathrm{z}}$ ”の 最大值は $1142.7 \mathrm{~N} / \mathrm{s}^{2}$ であった。歩行中の各最大值を閾 值とする。健常者では $2.1 \mathrm{~s}$ (転倒移行から $0.3 \mathrm{~s}$ 後), 模 擬高齢者では $1.8 \mathrm{~s}$ (転倒移行から $0.2 \mathrm{~s}$ 後)で $F_{\mathrm{z}}$ 'が閾值 を超えている。この時, 健常者の $F_{\mathrm{z}}$ ” も閾值を超えて いる。以上より，転倒移行から立ち直り反射の間で, $F_{\mathrm{z}}{ }^{\prime}$ が閾值を超えたかで転倒を判断する事が可能であ る。

転倒時は歩行器を前方向に押し出そうする力が加 わる為， $x$ 方向成分を含む $F$ が増加する。即ち， $F$ か らも転倒を判断する事が可能であると言える。 $F$ の場

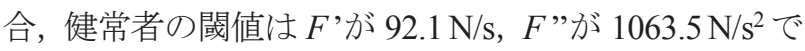

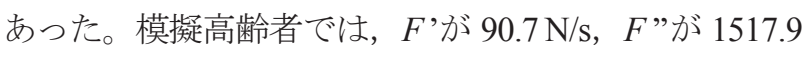
$\mathrm{N} / \mathrm{s}^{2}$ であつた。 $F_{\mathrm{z}}$ での転倒開始線から立ち直り反射線 までの間に $F_{\mathrm{z}}{ }^{\prime}, F$ ”が閾值を超えた時間は $F_{\mathrm{z}}$ のとほぼ 同時だった。

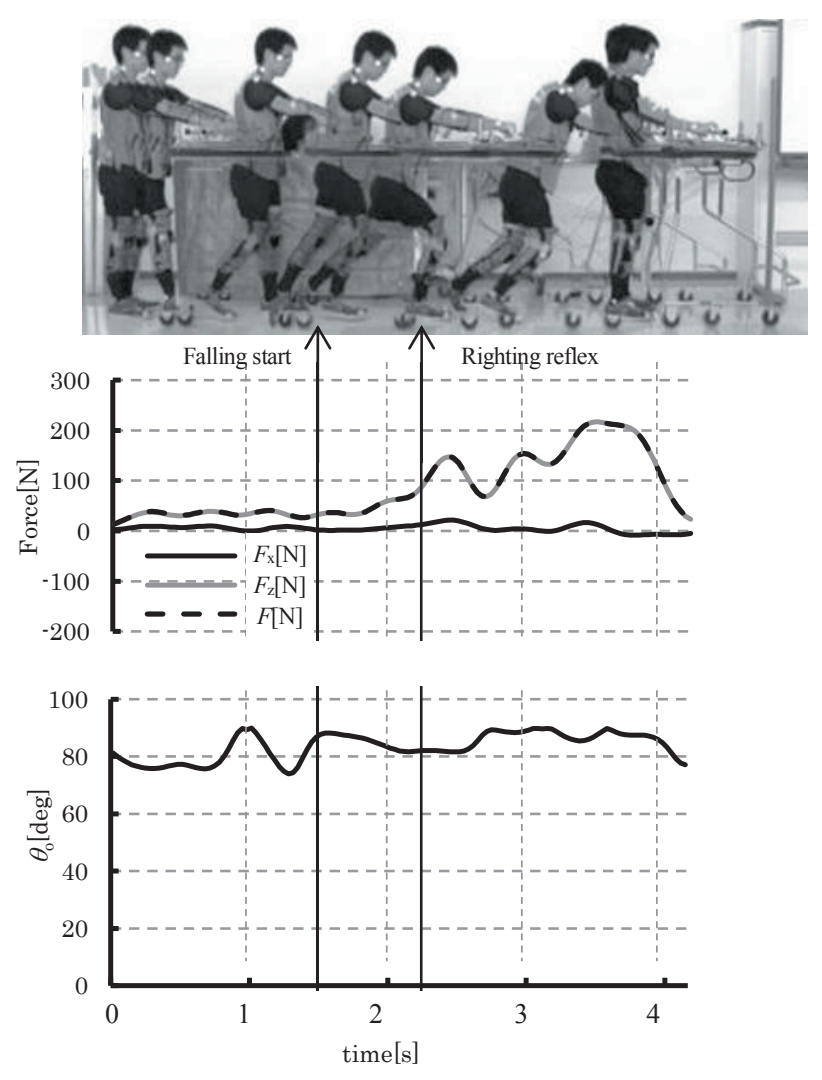

Fig. 9 Calculation of Resultant force $F$ and Direction $\theta$ (Simulated elderly people). 


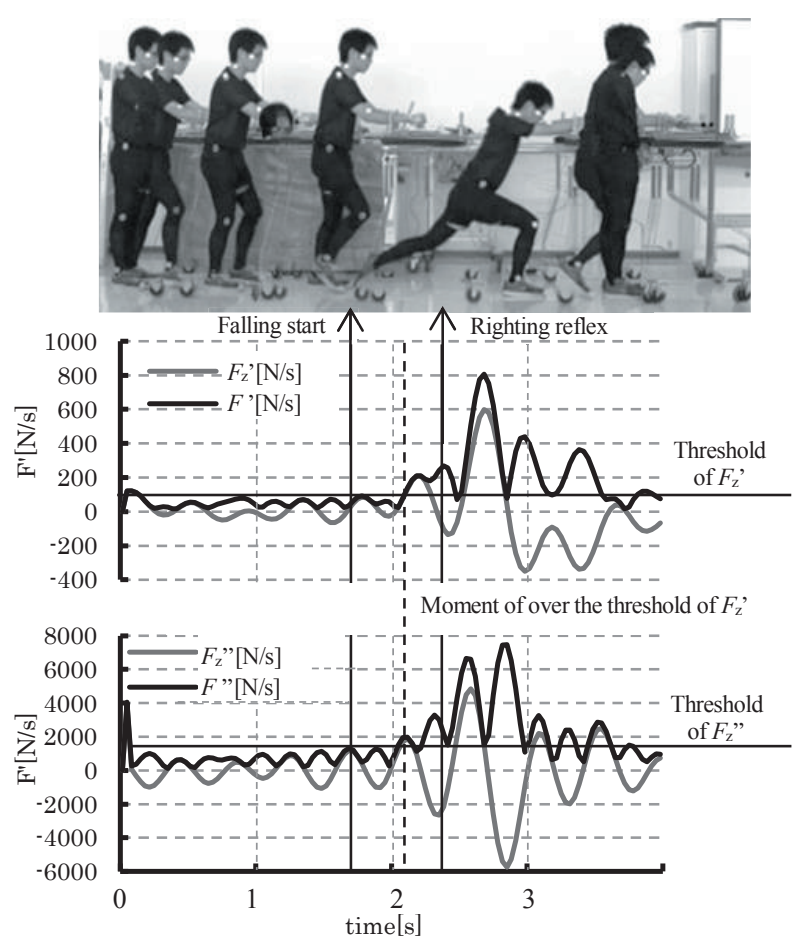

Fig. 10 Time variation of Force of vertical component and synthesis (Able-bodied person).

\section{3 考察}

以上より, 歩行器に作用する力 $F$ の時間変化である $F, F^{\prime}$, 及び $z$ 方向成分の時間変化である $F_{\mathrm{z}}{ }^{\prime}, F_{\mathrm{z}}{ }^{\prime}$ が 転倒判断指標とする。今回の実験では $F_{z}, F^{\prime}$ 'が閾值 を超える時間は転倒移行から $0.2 \sim 0.3 \mathrm{~s}$ 後であった。 転倒移行から立ち直り反射までは $0.8 \mathrm{~s}$ 程である。よっ て閾值以上の $F_{\mathrm{z}}{ }^{\prime}, F$ 'が検知された場合, 立位を保て なくなるまでの $0.5 \mathrm{~s}$ 間に車体の制御を行うことで, 転 倒を防止することが出来る。

\section{4 結言}

本研究では歩行器の転倒防止装置の開発に際して, 歩行器使用時の転倒を解析し転倒判断指標を検討した。 実験の結果, 歩行器に作用する力 $F$, 特に垂直方向に 作用する $F_{\mathrm{z}}$ において転倒時に急激な力の増加を確認 した。しかし現段階では被験者数が少ない為, 転倒判 断指標の確度を検証する必要がある。今後は $F_{\mathrm{x}}$ ” と $F_{\mathrm{z}}$ ” を転倒判断指標の候補とし, 複数の歩行条件と高齢者 の条件による転倒実験を行い, 指標の確度を検証する。

(2015 年 10 月 20 日受付, 2016 年 6 月 17 日再受付)

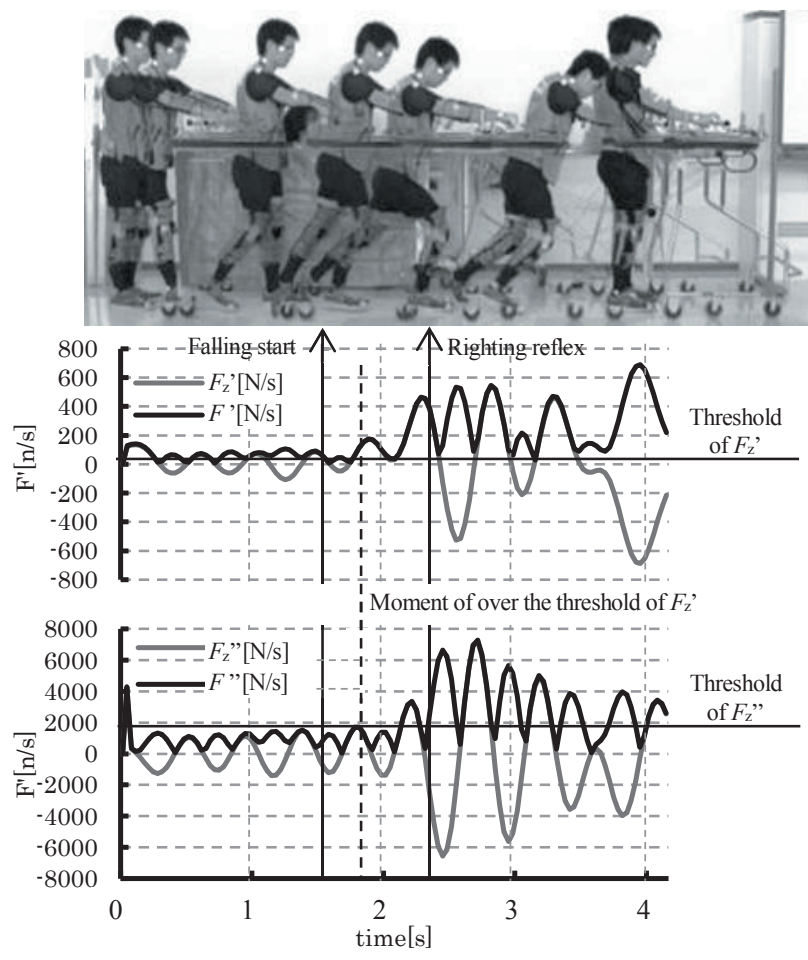

Fig. 11 Time variation of Force of vertical component and synthesis (Simulated elderly people).

\section{参考文献}

[1] 総務省, 人口推計，2012

[2] 厚生労働省, 平成 18 年身体障害児・者害態調査結果, 2008

[3] 厚生労働省, 日常生活自立度(寝たきり度)判断基準

[4] 安心院朗子, 徳田克己, 水野智美, 歩行補助車を使用し ている高齢者の外出状況と交通上の課題, 国際交通安全 学会誌, Vol. 35, No. 2, pp. 131-138, 2006

[5] 浜克己，川上健作，森谷健二，歩行支援機を用いた転倒 に関するメカニズムの解析とその防止, 函館工業高等専 門学校紀要, No. 41,pp. 7-12, 2007

[6] 上福元裕一, 和多田雅哉, 山田睦雄, 渡辺一郎, 椿原徹 也, 歩行器の転倒防止装置開発の為の転倒判断指標の計 測, 第 27 回「電磁力関連のダイナミクス」シンポジウム 講演集, pp. 501-506, 2015 